\title{
Value assessment of e-government service from municipality perspective
}

\author{
Jari Jussila \\ Virpi Sillanpää \\ Tampere University of Technology, \\ Finland \\ jari.j.jussila@tut.fi \\ Tampere University of Technology, \\ Finland \\ virpi.sillanpaa@tut.fi \\ Nina Helander \\ Tampere University of Technology, \\ Finland \\ nina.helander@tut.fi
}

\author{
Timo Lehtonen \\ Solita Plc., \\ Finland \\ timo.lehtonen@solita.fi
}

\begin{abstract}
Value assessment of e-government services remains a challenging task. In this study, we apply a value creation model of electronic business and value for money assessment approach of e-government service in an attempt to better understand value creation from the municipality perspective. By conducting semistructured interviews and analysis of e-government service data we investigate how digital service creates value in public services focusing on the municipality perspective. We present the identified sources of value and the indicators of value that could be derived from the analysis of data from the service. We discuss the complementary findings from performing value assessment using e-commerce and e-government models, the limitations of conducting value assessment of e-government services and performing financial analysis, and conclude with directions for future research.
\end{abstract}

\section{Introduction}

E-government services have been studied from a wide variety of perspectives, for example, as intention to use [6] and perceived risks [38,7] of e-government services, quality of e-government services [34], information systems (IS) procurement in the public sector $[27,28,26]$, benefits management and realization perspectives $[41,29,10,14]$, as well as, performance measurement and value for money assessment of egovernment [24,30,12,45]. More broadly in the IS literature several approaches have been proposed for value assessment of IS, such as financial $[32,43,13]$, economic $[16,13]$ and strategic approaches $[16,43,13]$. Value assessment and value creation studies on e- government and e-commerce have, however, mostly followed different tracks $[40,39,4]$.

In this paper the aim is to conduct a complementary study of an e-commerce and an e-government value assessment method for assessing the value of egovernment service from the municipality perspective. It has been recognized that there are significant differences between e-commerce and e-government related to e.g. different drivers, priorities and governing principles $[40,3,39,4]$. Nevertheless, ecommerce models have been used for value assessment of e-government e.g. [18].

The research question of the study can be formulated as how digitalization creates value in public services? We are especially interested in to assess the value of e-government service adoption from the viewpoint of the adopting municipalities. For this purpose we apply a value assessment model $[1,47]$ that has been extensively used in the context of e-business and has also been previously applied to e-government [18], together with and e-government value assessment approach $[2,45]$. The aim of using the two models is to provide more comprehensive understanding of value creation in an e-government service adoption phase, as the models consider a variety of value perspectives, not only limited to financial and economic perspectives.

In the empirical part of the research, we analyze the value created by the e-government service Lupapiste (freely translated "Permission desk"); a web site for managing municipal authorizations and permissions related to construction. The site has been developed by Solita Inc., a mid-sized Finnish software company that specializes in the design and implementation of web system, analytics and business intelligence [44].

In e-government services, various stakeholders can be identified ranging from individual citizens to government agencies and businesses [33]. All 
stakeholders have their roles, interests and value expectations towards e-government service. In this research, we focus on value e-government service creates from municipalities perspective.

\section{Theory}

\subsection{Defining Public Value}

Jørgensen and Bozemon [20] conducted an extensive review of public values universe of which they constructed and inventory consisting of seven value constellations: 1) public sector's contribution to society, 2) transformation of interests to decisions, 3) relationship between public administration and politicians, 4) relationship between public administration and their environment, 5) intraorganizational aspects of public administration, 6) behavior of public sector employees, and 7) relationship between public administration and the citizens. Related to value assessment of e-government service, especially the value constellations from 5-7 are relevant. These include values, such as public administration reliability, productivity and effectiveness, good working environment and selfdevelopment of public sector employees, and rule of law, equal treatment and responsiveness in the relationship between public administration and the citizens [20].

\subsection{Value assessment frameworks for e- government}

Several frameworks have been proposed for assessing value of government projects, including value for money audits - often referred to as the "Three Es" [15,31,30,12] or "Four Es". In addition there are a number of models that have been developed for value assessment of e-government projects at national level, such as eGEP Measurement framework [8], key indicators of good government and public services [23] and value framework for assessing egovernment impact [42].

The "Three Es" represent traditional value for money (VFM) audits consisting of three audit types: economy audit, efficiency audit and effectiveness audit [24,31,30,9,12]. Economy audit deals with how well the costs of resources (inputs) are minimized [24,12]. Efficiency audit relates to the relationship between output and input used to produce the service, i.e. providing a specified volume and quality of service with the lowest level of resources capable of meeting that specification [24,12]. Efficiency can be further divided to resource efficiency and administrative process (or flow) efficiency, where the latter focuses on the government's efficiency in executing its routine operations [42,25,21]. Effectiveness audit focuses on the extent to which the organization is able to implement policies and achieve its objectives. [24,12]

The "Four Es" approach adds the concept of equity to the "Three Es" approach and considers for whom an organization is economical, efficient and effective $[2,11,36]$. Bailey's [2] concept of horizontal equity refers to treating equally people, households or groups in equal circumstances [36].

\subsection{Amit and Zott value creation model}

In addition of the value assessment framework of "Four Es" presented in previous section, a complementary approach is used to offer more holistic understanding of the research phenomenon. This complementary approach builds on the value creation model of Amit and Zott [1], which was originally designed to illustrate sources of value creation in the field of electronic business and has since been applied also to e-government [18]. In the model, four major value drivers in e-business are identified: efficiency, complementarities, lock-in and novelty. The model, originally built for e-commerce purposes, has been applied to e-government context as it focuses on analyzing value creation [18] that should be also included as a key aspect in the public government studies more intensively than previous research has done [17]. For the purposes of the present study, that is to assess the value of e-government service adoption from the viewpoint of the adopting municipalities, this approach gives a fresh view.

Increasing the efficiency of the processing of transactions in e-business leads to lower costs and hence to higher value. The potential of lower costs is enabled for example by reducing searching costs through reducing information asymmetries between buyers and sellers via providing comprehensive and up-to-date data. Another example of source of efficiency is the speed with which information can be transmitted via the Internet [1] or the reduction of asymmetry of information [18].

Complementarities, as another value driver, occur if a bundle of goods and/or services together create more value than the total value of having each of the goods separately. One example for complementarities are internet-based services [19], such as Skype. Goods and services are linked in a reasonable way, which generates value. Complementarities can be vertical, like after-sales services, and horizontal, like cameras and memory card. Beyond that, the connection between off-line and on-line assets is a further 
complementarity. It supports the customers to establish contacts and to process transactions [1].

The lock-in of other actors to one's own company can be divided into two directions, on the one hand, on the willingness of customers to repeat transactions, and on the other hand, by the extent to which strategic partners are motivated to maintain and improve their collaboration. Lock-in prevents customers as well as strategic partners to migrate to competitors. This leads to higher transaction rates and lower costs. For example, loyalty programs (e.g. bonus cards), dominant design property standards, and the establishment of trustful relationships with customers are leading to customer retention. In a previous study that applied the Amit \& Zott model to e-government services [18] it was highlighted that the lock-in in this context could be especially referred as the unwillingness to change from the traditional offline, non-digital service to the online, digital service, or vice versa. They also pointed out that one potential way to create lock-in in e-government service context is the possibility to empower the citizens.

Moreover, e-business enables that customers can customize products and services, as well as information, which leads to enhanced lock-in. Personalized websites offer customers the possibility to create personalized profiles, where they can add their own preferences. Virtual communities for example, bond participants to a special e-business, which creates loyalty, enables frequent interactions, and enhance the frequency of transactions [1]. Hence, it is easier for a company to create migration barriers for customers and strategic partners, and to hold the network stable.

In this context, network externalities are another important aspect [5]. According to Katz and Shapiro, positive network externalities arise when utility for the user of a product increases with the number of agents that consume the product [22]. In e-business, network externalities can be found when the created value for customers rises with the quantity of the customer base. That means that a user-community becomes more attractive for potential members to join a community after a new member has subscribed to the community. Otherwise, if a community loses members the platform becomes unattractive and the member dropout rate may increase. Besides, indirect network externalities may arise when economic agents benefit from positive feedback loops of other agents. While having a look of e-bay or other online auction sites, it is visible that buyers do not benefit from other buyers. But the existence of a multiplicity of buyers makes the platform more attractive for potential sellers. This again leads to an increasing desirability on the site to potential buyers. Hence, buyers benefit indirectly from an increasing amount of other buyers. This applies also to sellers [1].

The fourth source of value creation that Amit and Zott mention is novelty. Novelty includes the traditional value drivers like new products or services, distribution, new methods of production, or marketing. But additionally, e-business innovates new ways in structuring transactions. Connecting parties, which were previously unconnected, creates value in terms of eliminating inefficiencies in the process of buying and selling through adopting innovative transaction methods, creating entirely new markets, and capturing latent customer needs [1].

The sources of value creation are illustrated in Figure 1.

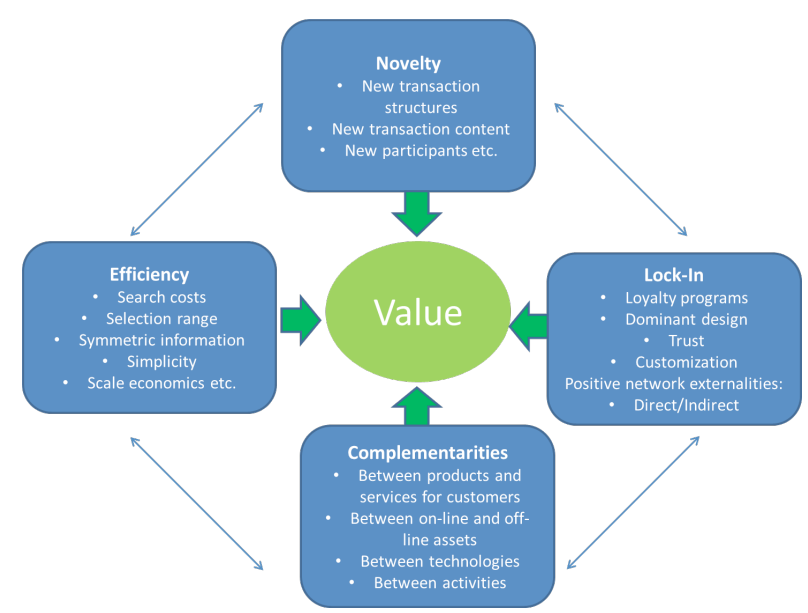

Figure 1. Sources of value creation.

\section{Research Approach}

\subsection{Lupapiste e-government service}

Lupapiste service was developed as a part of Action Programme on eServices and eDemocracy (SADe programme) set by the Ministry of Finance in Finland. The purposes of the programme was to provide interoperable, high-quality public sector services via digital channels to improve cost-efficiency, create savings, and generate benefits to citizens, businesses, organisations and local and government authorities. Special attention was paid to the achievement of cost benefits to municipalities. The programme involved the development of electronic services in seven projects. Programme period was 2009 - 2015, and the budget for the total SADe Programme was about $70 \mathrm{M} €[35]$.

Lupapiste was one of the sub-projects in the programme coordinated by Ministry of Environment. In addition to Lupapiste, Ministry of Environment 
coordinated six other projects, and total budget for those projects was 11,5 M€.

The SADe programme did not achieve targeted outcomes, especially in terms of cost-efficiency [46]. Identified challenges hindering the realization of benefits related to lack of business models for eservices; for example, decisions regarding ownerships, implementation and dissemination (i.e. marketing) of services were not made early enough. In addition, development and management of e-services were not integrated with the public service provision.

According to programme evaluation [46] Lupapiste was rated as the most successful project coordinated by Ministry of Environment in terms of benefits created to municipalities. In addition, Lupapiste was by far the most well-known service of the sub-programme, and the implementation of the service was considered successful.

After a competitive bidding, Solita Inc. was chosen as a service provider for Lupapiste. Lupapiste service was developed in co-operation with municipalities that worked as pilots in the project. Lupapiste is a webbased open source service that enables digital application of construction permits and other permits related to infrastructure. Lupapiste is compatible with software that municipalities use in managing and archiving documents related to construction activities. Pricing of the service is divided into two parts: monthly payment, which depends on the size of the municipality and payments per transactions, which is dependent upon the total number of applications in the service (i.e. more applications nationwide, lower the price per application). In addition, Solita Inc. offers complementary services, like electronic archiving, training and consultancy services.

\subsection{Research design and methods}

Our aim was to investigate how digital service creates value in public services focusing on the municipality perspective. More specifically, our starting point was the Business-to-Government (B2G) relationship between E-government service provider and municipality and also the internal effectiveness and efficiency (IEE) and Government-to-Employee (G2E) relationship in the municipalities [39]. Interviews and data collection from the E-government service were chosen as research methods to investigate these relationships.

The empirical data is consisted of qualitative interview data complemented by e-mail survey conducted after interviews, and a wide set of quantitative log data from the Lupapiste service. The research group consisted of four researchers, of which three were involved in the interviews and analyzing the interview data, and two were involved in the analysis of data from the E-government service. Of the researchers one has several years of experience in measuring performance of public services, one researcher has extensive experience on value creation and E-commerce research, one is experienced in research of digital services and big data analysis, and one is expert on software development and data engineering.

For the qualitative data we carried out 10 semistructured interviews [37] in 5 municipalities ranging from small to large (inhabitants varying from 19000 to 210 000). All participating municipalities were pilots in the development project SADe.

Before interviews we familiarized with the topic by having a workshop at Solita, including staff from sales, product development and service support. The aim of the workshop was to identify different stakeholder groups related to Lupapiste, and identify value proposals (potential value) that Lupapiste creates to different stakeholder groups.

After the workshop, an expert interview with a leading building inspector from a municipality that was very active in Lupapiste development and implementation was carried out. Themes of the interview and structure of the interview was decided after the workshop and expert interview.

In each municipality, building inspector or leading building inspector and person from customer service (usually office secretary or customer service secretary) was interviewed (Table 1). Themes of the interviews included: motivation for the introduction of Lupapiste, benefits and challenges related to the introduction and use of Lupapiste, the functionality of the system and feedback to the service provider. Interviews were tape recorded and transcribed later, and transcribed interview data was available to all three researchers, which enabled triangulation of the data. Interviews were tape recorded and transcribed later, and transcribed interview data was available to all three researchers, which enabled triangulation of the data.

To complement the empirical study with Four E's perspective, interviewees were asked to answer short survey concerning economy, efficiency, effectiveness and equity related to Lupapiste service. Three municipalities replied the survey.

Table 1. Interviews conducted.

\begin{tabular}{|l|l|l|}
\hline $\begin{array}{l}\text { Muni- } \\
\text { cipality }\end{array}$ & Roles of interviewees & $\begin{array}{l}\text { Number of } \\
\text { interviews }\end{array}$ \\
\hline Vantaa & $\begin{array}{l}\text { Director, supervision of } \\
\text { building } \\
\text { Secretary, supervision of } \\
\text { building }\end{array}$ & 1 \\
\hline Hyvinkää & Building inspector & 1 \\
\hline
\end{tabular}




\begin{tabular}{|l|l|l|}
\hline & $\begin{array}{l}\text { Secretary, customer } \\
\text { service }\end{array}$ & 1 \\
\hline Sipoo & $\begin{array}{l}\text { Manager, supervision of } \\
\text { building } \\
\text { Secretary, supervision of } \\
\text { building }\end{array}$ & 1 \\
\hline Kuopio & $\begin{array}{l}\text { Engineer, construction } \\
\text { permit } \\
\text { Secretary, supervision of } \\
\text { building }\end{array}$ & 1 \\
\hline Mikkeli & $\begin{array}{l}\text { Leading building } \\
\text { inspector } \\
\text { Office secretary }\end{array}$ & 1 \\
\hline
\end{tabular}

Two municipalities out of 5 were chosen to our value creation analysis. Both municipalities had been pilot organizations in SADe program. Lupapiste was introduced in both municipalities during the year 2014.

Municipality A is a large, proactive, "successful" municipality who has digitalized the whole construction permit application process. In the Municipality A, all one-family houses were managed through Lupapiste, starting from November 2014 and from November 2015 Lupapiste was applied in all applications for building permits in the municipality. Implementation of Lupapiste was connected to a larger strategic program that took place in the municipality at the same time, and aimed at improving municipality's ability to serve citizens. The implementation of Lupapiste was supported by a performance bonus system that was applied to whole personnel in the office of supervision of construction.

Municipality B is a relatively small municipality, which has made decision to move all construction applications to Lupapiste by August 2016. There was a gap in the implementation process due to changes in the personnel; two persons responsible for the implementation left during 2014, which caused additional challenges in the implementation phase. In Municipality B Lupapiste is part of development project aiming at creating more efficient public services by digitalization. Along with the new manager of the unit and dedicated in-house coordinator, Municipality B is now aiming to digitalize the whole process in 2016. At the time of the interviews (spring 2016) there were two parallel application processes in use in the Municipality B (paper and digital process).

The "Four Es" analysis was extended to all of the five municipalities.

\section{Results}

The aim of this research was to find out how digitalization creates value in public services. In this research we applied theoretical model of sources of value creation in e-business developed by Amit and Zott [1] and the "Four Es" [2] model to identify what value that new type of digital service, Lupapiste, creates to its municipal customers in public sector. Table 2 illustrates identified sources in value creation in Municipalities A and B in this study. (Color grey in the table symbolizes expected sources of value).

\subsection{Analysis using Amit and Zott model}

Efficiency. In the interviews, many types of benefits related to efficiency were identified. Savings related to printing costs were considerable for both municipal authorities and customers, since printing large plans that was required before digital service, is costly. In addition, working time was spent when assistants didn't have to print or scan documents. When documents are in digital format, physical space is saved, which indicates savings in office space and cost savings for the department. Ability to process applications 24/7 wherever internet connection is available increased flexibility of work by enabling flexible working hours and remote work, the option that $1 / 3$ of employees in the Municipality A utilized. Because of declined amount of customer visits, work in customer service was perceived more flexible; now personnel can reply to questions online, and the pressure created by customers standing in line is eased. In addition, digital management of application processes create savings in travel costs and work times, since different authorities can make their statements in Lupapiste instead of having face-to-face meetings. Cost savings were underlined especially in the Municipality A, which had digitalized the whole application process. Interviewees in the Municipality B identified many similar potential savings that will be realized when application process is fully digitalized.

Productivity improvements related to increased ability to utilize resources; especially building inspectors had more time to focus on their core tasks instead of searching for paper files and documents, which ended up productivity improvements of $65 \%$ in application handling (with the same amount of personnel) in the Municipality A.

Lupapiste reduces information asymmetries by adding transparency between authorities and customers. Transparency is considered as one of the major benefits related to Lupapiste. Now all parties involved in the application process have access to the latest information regarding the process, which enables faster and more informed decision-making. Transparency also declines the amount of customer visits and phone calls and thus improves overall 
productivity (both from customer and municipality perspectives).

Novelty. Digital management of application process is new type of service for municipalities and it entails many benefits that indicate novelty dimension as a source of value creation. Municipality A underlined the role of Lupapiste as a platform for more intense cooperation with customers; e.g. now very specified 3D digital models of certain districts and neighborhoods can be made in planning phase, which benefits the decision making. Lupapiste offers a social media channel (Yammer) for its customers to discuss about construction permit application processes and other topics related to construction and the use of digital service. Thus Lupapiste has created a virtual community that bond participants and has facilitated co-operation between municipalities. As a small organization Municipality B appreciated the communication with authorities in other municipalities and co-operation and support it has received.

Lock-in. As open-source software developed initially by the public funding, Lupapiste is not able to "lock" customers in the service. Customers can stop using the software if they want, and customer's data is transferred easily to customer's own databases. Municipalities are aware of this, and especially Municipality A indicated that they are capable to develop the service on their own if co-operation with the service provider didn't work and if the service provider was not agile enough. We interpret that in this service lock-in relates to improving customer loyalty, since it is the only way to motivate municipalities to engage in repeat transactions in Lupapiste, since there are also other service providers available. Possibility to develop the service together with the service provider was appreciated especially in the Municipality A; for example, developers from Solita had worked three days in the office of supervision on construction unit to develop the service together with the personnel of the municipality. In addition, both municipalities appreciated customer service and support provided by Solita. Both municipalities have dedicated contact persons that coordinate communication to Solita. Customer support was easily available to all service users and was considered very service-minded.

Complementarities. These refer to situation when having bundle of goods together provides more value than having each of the goods separately. In this research, Skype, electronic archiving and software developed for electronic sales of construction plans were mentioned as complimentary products that create value when used together with Lupapiste. In Municipality A part of face-to-face meetings were replaced with Skype-calls, when all parties had access to documents in Lupapiste. Municipality A had a software called "Arska" in use for electronic sales of construction plans, and Lupapiste was compatible with it, which indicated savings in scanning of drawings etc. Both municipalities were looking forward to electronic archive that was about to get launched during the spring 2016, since it would enable digitalization the whole process; now municipalities had to print focal documents (e.g. master plans) for archives, that were still in paper format. Along with the digital archives, paper prints are not required anymore.

Table 2. Sources of value creation in Municipalities $A$ and $\mathrm{B}$.

\begin{tabular}{|c|c|c|}
\hline & $\begin{array}{c}\text { Municipality } \\
\text { A }\end{array}$ & $\begin{array}{c}\text { Municipality } \\
\text { B }\end{array}$ \\
\hline \multicolumn{3}{|l|}{ Efficiency } \\
\hline Cost savings & $\mathrm{x}$ & $\mathrm{x}$ \\
\hline Transparency & $\mathrm{x}$ & $\mathrm{x}$ \\
\hline $\begin{array}{l}\text { Productivity } \\
\text { improvements }\end{array}$ & $\mathrm{x}$ & $\mathrm{x}$ \\
\hline Flexibility & $\mathrm{x}$ & $\mathrm{x}$ \\
\hline \multicolumn{3}{|l|}{ Novelty } \\
\hline $\begin{array}{l}\text { More intensive co- } \\
\text { operation with } \\
\text { customers }\end{array}$ & $\mathrm{x}$ & \\
\hline $\begin{array}{l}\text { Communication and } \\
\text { co-operation with } \\
\text { other municipalities }\end{array}$ & & $\mathrm{x}$ \\
\hline \multicolumn{3}{|l|}{ Lock-in } \\
\hline $\begin{array}{l}\text { Agile product } \\
\text { development }\end{array}$ & $\mathrm{x}$ & \\
\hline $\begin{array}{l}\text { Active customer } \\
\text { service and support }\end{array}$ & $\mathrm{x}$ & $\mathrm{x}$ \\
\hline \multicolumn{3}{|l|}{ Complementarities } \\
\hline Skype & $\mathrm{x}$ & \\
\hline Electronic archiving & $\mathrm{x}$ & $\mathrm{x}$ \\
\hline $\begin{array}{l}\text { Electronic sales of } \\
\text { construction plans } \\
\text { (Arska) }\end{array}$ & $\mathrm{x}$ & \\
\hline
\end{tabular}

\subsection{Analysis using Four E's model}

Economy. Results of interviews and survey indicate that Lupapiste service is able to create more saving, if the process if fully digitalized. Municipalities which used only digital permit application process reported cost savings related to printing, working hours, office space and travelling. However, municipalities that were in the early phase of implementation, considered digitalization causing extra costs in terms of 
investments in hardware (computers and larger screens), use fee of Lupapiste, and learning time needed. Regardless of the implementation phase, most of municipalities considered that Lupapiste is able to create savings to customers (citizens and corporate customers) in terms of travel, time and printing costs.

Efficiency. As noticed in the earlier analysis based on Amit \& Zott's model, Lupapiste increases efficiency in many ways, like enabling specialists to focus on their core tasks instead of carrying out of routines, when it is fully implemented (e.g. in Municipality A). Fact that authorities can make their statements in Lupapiste and possibility to work on travel were factors affecting positively the efficiency of construction permission departments operation.

Effectiveness. Based on the empirical data, Lupapiste was clearly connected to achieving strategic goals of the municipality, i.e. digitalization of municipal services.

Equity. According to respondents, Lupapiste service increased equity by enabling construction application for customers that live in another part of the country. Some respondents underlined the fact that digitalized service, like Lupapiste, requires competence of using software which may be too high requirement for elderly people or people with disabilities. However, according to replies, the most of applicants are young people or companies (architects, designers).

\subsection{Analysis from E-government service data}

In addition to the interviews, we carried out an analysis of the actual Lupapiste data. We started out by investigating the adoption of digital construction permit services in the two Municipalities. Figure 2 outlines the growth in digitally processed constructing permits. We included only construction permit applications that were related to construction of buildings, excluding application categories or operations such as assigning site manager, cutting down trees or infrastructure related applications.

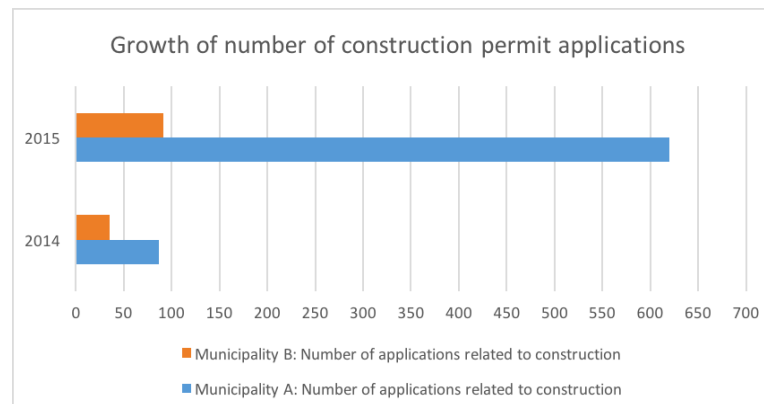

Figure 2. Growth of number of construction permits processed digitally in Municipality A and Municipality B between the years 2014 and 2015 .
As a second indicator of the adoption of digital construction permit services, we investigated the growth of the number of different application categories or operations that have been digitalized in the municipalities. Figure 3 outlines the growth in terms of number of digital construction permit categories adopted by the municipality.

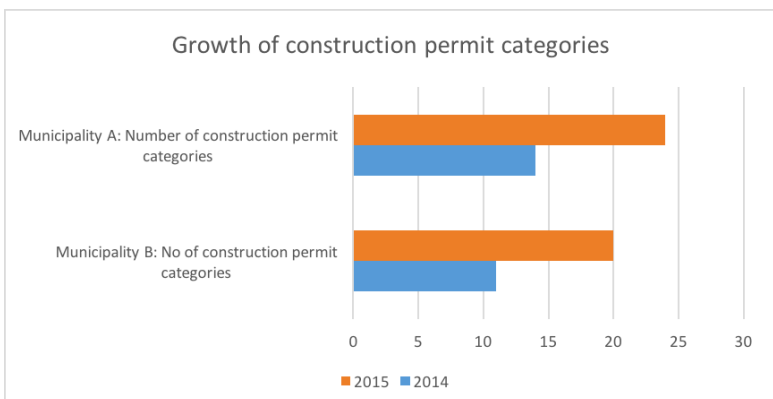

Figure 3. Growth of construction permit categories digitalized in Municipality A and Municipality B between the years 2014 and 2015

In order to measure the impact of digitalization of construction permits processing we calculated the leadtimes of the approved applications for each municipality.

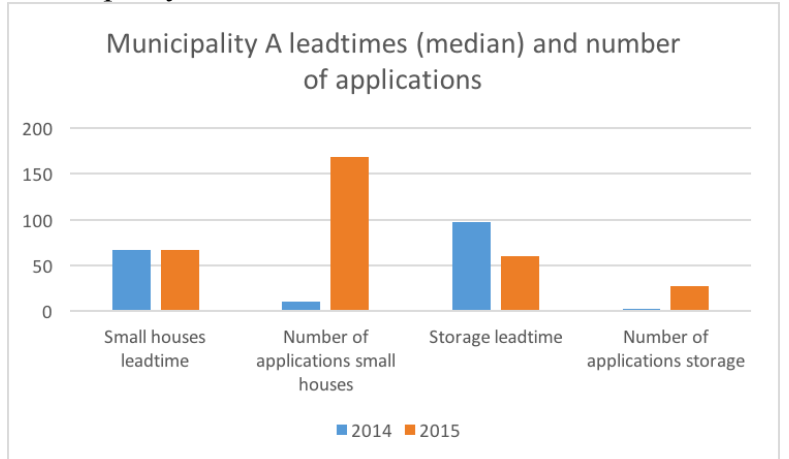

Figure 4. Municipality A: median leadtimes and number of applications in each selected application category.

As can be seen on the Figure 4, the median leadtimes have remained the same for small houses and shortened for the storage buildings. The number of processed applications of small houses and storage buildings have increased significantly from the year 2014. 


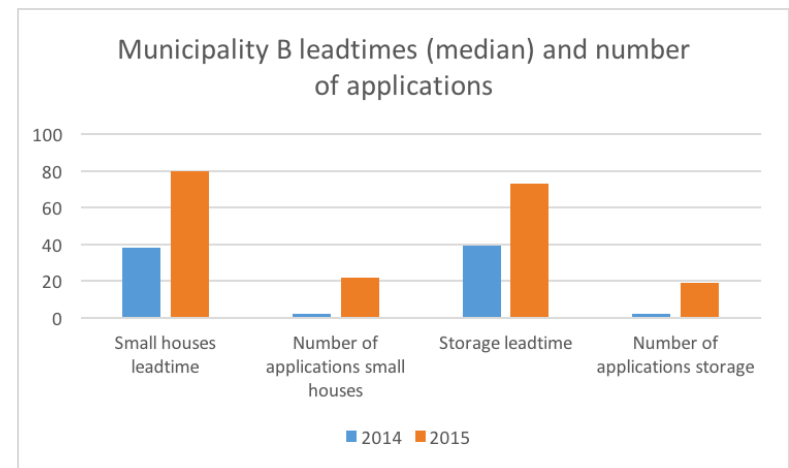

Figure 5. Municipality B: median leadtimes and number of applications in each selected application category.

From the Figure 5 it can be observed that the number of applications have increased, but so have also the median leadtimes increased from the year 2014 to the year 2015 in Municipality B. The major difference is that Municipality B is processing both digital and paper applications, whereas Municipality A processes only digital applications.

\section{Conclusions}

Our aim was to investigate how digital service creates value in public services focusing on the municipality perspective. Our starting point was to analyze the value e-government service creates in terms of Business-to-Government (B2G) relationship (between e-government service provider and municipality) and also the internal effectiveness and efficiency (IEE) and Government-to-Employee (G2E) relationship in the municipalities [39]. While conducting interviews we recognized that the digital service creates value also in other relationships: in Government-to-Government (G2G) by improving cooperation between municipalities. This type of digital service was found to enable virtual municipality cooperation model, where authority form one municipality can process construction application from another municipality. However, the realization of value created through virtual municipality co-operation model requires changes to work and administrative processes, which are commonly identified requirements in both e-Commerce and e-Government research [39].

Financial and economic assessments turned out to be challenging to conduct for municipalities that have only recently implemented or are still in the adoption phase of e-government services.

The results from the interviews and data-analysis provided several insights for the implementation and value assessment of e-government services. First, the analysis indicates that digital service creates more value if it can be implemented more rapidly and completely without a parallel digital and paper application processing. Second, digital service can create significant cost savings that derive from multiple sources, e.g. savings in travel costs, printing and scanning costs, and information search costs. Third, digital service creates a platform for new type of collaboration, which requires changes to administrative and work processes. Fourth, lock-in to service provider is not a good approach for e-government services, a better approach is to built customer loyalty, motivate customers to use the service, offer additional services and the opportunity to participate in the development of the product. Fifth, Amit and Zott [1] model helps to uncover multiple sources of value even during the implementation phase of digital service. On the other hand, some value drivers seem to impact each other, and it is at times difficult to classify sources of value only under one heading, e.g. network, and community related value fit both to novelty and customer loyalty.

At the time of the study, municipalities had implemented Lupapiste relatively recently, or were still in adoption phase, which indicates that all potential benefits are not yet realized. For example the forthcoming complementary services, i.e. electronic archiving, could facilitate municipalities to benefit even more of the Lupapiste. In addition, Lupapiste offers platform for many co-development activities; for example municipalities could share tasks according to core competencies, e.g. one municipality could manage all construction permits related to apartment buildings in a certain area. However, platform alone is not adequate to ensure that all potential benefits are realized, also changes to processes and working methods are needed.

According to our research, municipalities lack indicators that could be utilized in value assessment of e-government services - even though in both of the case study municipalities the implementation of egovernment services was linked to strategic development goals of the municipality. Our study suggests how data from e-government service can be used as indicators related to the efficiency of processes, and thus supports operations management in municipalities. Various additional indicators related to value creation can be developed from the data: for example measures related to flexibility (e.g. ratio of applications processed outside organization's premises and office-hours) and efficiency (e.g. flow efficiency of applications). Thus, e-government service provides potential for more elaborated performance measurement in municipalities.

We discovered that Amit \& Zott's of value creation is able to assess fairly well value expected from e- 
government in terms of economy, efficiency and effectiveness. However, the model lacks one of the focal perspectives of "Four E's", namely equity.

In this study only value created to municipalities in B2G, IEE and G2E relationships was analyzed - value created to other stakeholder groups like businesses (construction and engineering companies) or citizens was out of the scope of this research. In addition, value that new business model created to the service provider was not analyzed in this study. Thus, further research is needed in order to analyze value created by egovernment service in these contexts.

\section{References}

[1] Amit, R. and Zott, C. Value creation in e-business. Strategic management journal 22, 6-7 (2001), 493-520.

[2] Bailey, S.J. Strategic public finance. Palgrave Macmillan, 2004.

[3] Barzilai-Nahon, K. and Scholl, H.J. Similarities and differences of e-Commerce and e-Government: Insights from a pilot study. System Sciences, 2007. HICSS 2007. 40th Annual Hawaii International Conference on, IEEE (2007).

[4] Barzilai-Nahon, K. and Scholl, H.J. Siblings of a different kind: e-Government and e-Commerce. International Conference on Electronic Government, Springer (2010), 2537.

[5] Bernhardt, J., Helander, N., Jussila, J., and Kärkkäinen, H. Crowdsourcing in Business-to-Business Markets: A Value Creation and Business Model Perspective. In Encyclopedia of E-Commerce Development, Implementation, and Management. IGI Global, 2016, 933-943.

[6] Carter, L., Schaupp, L.C., and Evans, A. Antecedents to e-File adoption: the US perspective. Hawaii International Conference on System Sciences, Proceedings of the 41st Annual, IEEE (2008), 216-216.

[7] Carter, L., Schaupp, L.C., Hobbs, J., and Campbell, R. Egovernment utilization: understanding the impact of reputation and risk. International Journal of Electronic Government Research (IJEGR) 8, 1 (2012), 83-97.

[8] Codagnone, C., Boccardelli, P., and Leone, M. eGovernment Economics, Project (eGEP): Measurement Framework Final Version. eGovernment Unit, DG Information Society and Media, European Commission, http://82.187 13, (2006).

[9] Dittenhofer, M. Performance auditing in governments. Managerial Auditing Journal 16, 8 (2001), 438-442.
[10] Flak, L.S. and Solli-Saether, H. Benefits Realization in eGovernment: Institutional Entrepreneurship or Just Hype? System Sciences (HICSS), 2013 46th Hawaii International Conference on, IEEE (2013), 2062-2071.

[11] Frederickson, H.G. Social Equity and Public Administration: Origins, Developments, and Applications. Taylor \& Francis, 2010.

[12] Grönlund, A., Svärdsten, F., and Öhman, P. Value for money and the rule of law: the (new) performance audit in Sweden. International Journal of Public Sector Management 24, 2 (2011), 107-121.

[13] Gunasakeran, A., Ngai, E.W.T., and McGaughey, R.E. Information technology and systems justification: A review for research and application. European Journal of Operational Research 173, (2006), 957-983.

[14] Hellang, Ø., Skiftenes Flak, L., and Päivärinta, T. Diverging approaches to benefits realization from public ICT investments: A study of benefits realization methods in Norway. Transforming Government: People, Process and Policy 7, 1 (2013), 93-108.

[15] Holtham, C. and Stewart, J. Value for Money: A Framework for Action. Institute of Local Government Studies, University of Birmingham, 1981.

[16] Irani, Z., Love, P.E., and others. Developing a frame of reference for ex-ante IT/IS investment evaluation. European Journal of Information Systems 11, 1 (2002), 74-82.

[17] Janssen, M., Kuk, G., and Wagenaar, R.W. A survey of Web-based business models for e-government in the Netherlands. Government Information Quarterly 25, 2 (2008), 202-220.

[18] Järveläinen, J., Koskivaara, E., Pihlaja, P., Salmela, H., and others. Value-creating e-government business models for early childhood education in Finland. International Journal of Electronic Government Research 3, 3 (2007), 72.

[19] Johansson, N. and Mollstedt, U. Revisiting Amit and Zott's model of value creation sources: The SymBelt Customer Center case. JTAER 1, 3 (2006), 16-27.

[20] Jørgensen, T.B. and Bozeman, B. Public values an inventory. Administration \& Society 39, 3 (2007), 354-381.

[21] Jussila, J., Helander, N., Sillanpää, V., Lehtonen, T., and Kallio, J. Can e-government solutions enhance the work in municipalities? Empirical evidence from case Lupapiste. Academic MindTrek Conference Proceedings, ACM (2016). http://dx.doi.org/10.1145/2994310.2994357

[22] Katz, M.L. and Shapiro, C. Network externalities, competition, and compatibility. The American economic review 75, 3 (1985), 424-440. 
[23] Lonti, Z. and Woods, M. Towards Government at a Glance. (2008).

[24] Midwinter, A. Developing performance indicators for local government: the Scottish experience. Public money \& management 14, 2 (1994), 37-43.

[25] Modig, N. and Åhlström, P. This is lean: Resolving the efficiency paradox. Rheologica, 2012.

[26] Moe, C.E. and Newman, M. The Public Procurement of IS-A Process View. System Sciences (HICSS), 2014 47th Hawaii International Conference on, IEEE (2014), 21582167.

[27] Moe, C.E. and Päivärinta, T. Challenges in information systems procurement in the Norwegian public sector. In Electronic Government. Springer, 2011, 404-417.

[28] Moe, C.E. and Päivärinta, T. Challenges in information systems procurement in the public sector. Electronic Journal of e-Government 11, 1 (2013).

[29] Päivärinta, T., Dertz, W., and Flak, L.S. Issues of Adopting Benefits Management Practices of IT Investments in Municipalities: A Delphi Study in Norway. System Sciences, 2007. HICSS 2007. 40th Annual Hawaii International Conference on, IEEE (2007), 103-103.

[30] Pollitt, C., Girre, X., Lonsdale, J., et al. Performance or compliance?: performance audit and public management in five countries. OUP Catalogue, (1999).

[31] Power, M. The audit society: Rituals of verification. OUP Oxford, 1997.

[32] Renkema, T.J. and Berghout, E.W. Methodologies for information systems investment evaluation at the proposal stage: a comparative review. Information and Software Technology 39, 1 (1997), 1-13.

[33] Rowley, J. e-Government stakeholders-Who are they and what do they want? International journal of Information management 31, 1 (2011), 53-62.

[34] Sá, F., Rocha, Á., and Cota, M.P. From the quality of traditional services to the quality of local e-Government online services: A literature review. Government Information Quarterly, (2015).

[35] Saarijärvi, M., Alanko, I., and Nurminen, P. SADeohjelma (Sähköisen asioinnin ja demokratian vauhdittamisohjelma). 2016.

[36] Santandrea, M., Bailey, S.J., and Giorgino, M. Infrastructure funding and financing: achieving value for money in public-private partnerships. financing new infrastructures in the international debt and post-financial crisis era, Venice, (2013).

[37] Saunders, M., Lewis, P., and Thornhill, A. Research Methods For Business Students. Pearson Education, Harlow, 2009.

[38] Schaupp, L.C., Carter, L., and McBride, M.E. E-file adoption: A study of US taxpayers' intentions. Computers in Human Behavior 26, 4 (2010), 636-644.

[39] Scholl, H.J., Barzilai-Nahon, K., Ann, J.-H., Popova, O.H., and Re, B. E-Commerce and e-Government: How do they Compare? what can they Learn from each Other? System Sciences, 2009. HICSS'09. 42nd Hawaii International Conference on, IEEE (2009), 1-10.

[40] Scholl, H.J.J. What can e-Commerce and e-Government learn from each other? Proceedings of the 2006 international conference on Digital government research, Digital Government Society of North America (2006), 454-455.

[41] Skiftenes Flak, L., Dertz, W., Jansen, A., Krogstie, J., Spjelkavik, I., and Ølnes, S. What is the value of eGovernment-and how can we actually realize it? Transforming Government: People, Process and Policy 3, 3 (2009), 220-226.

[42] Srivastava, S.C. and Teo, T.S. E-government payoffs: Evidence from cross-country data. Journal of Global Information Management 15, 4 (2007), 20.

[43] Stix, V. and Reiner, J. IT appraisal methods and methodologies: a critical literature review. Innovations through information technology. Information Resources Management Association International Conference, New Orleans, Louisiana, USA, (2004).

[44] Tyrväinen, P., Saarikallio, M., Aho, T., Lehtonen, T., and Paukeri, R. Metrics Framework for Cycle-Time Reduction in Software Value Creation. ICSEA 2015: The Tenth International Conference on Software Engineering Advances, ISBN 978-1-61208-438-1, IARIA (2015).

[45] Virtanen, P. and Vakkuri, J. Julkisen toiminnan tuloksellisuusarviointi. Tietosanoma, Helsinki, Finland, 2016.

[46] Wennberg, M., Oosi, O., and Korhonen, N. Selvitys rakennusalan toimilupajärjestelmästä. (2015).

[47] Zott, C. and Amit, R. Business model design: an activity system perspective. Long range planning 43, 2 (2010), 216226. 